\title{
Serological diagnosis of Toxoplasma gondii: analysis of false-positive IgG results and implications
}

Loïc Simon $^{1,2, *}$, Judith Fillaux ${ }^{3,4}$, Aurélie Guigon ${ }^{5}$, Rose-Anne Lavergne ${ }^{6,7}$, Odile Villard ${ }^{8}$, Isabelle Villena ${ }^{9}$, Pierre Marty ${ }^{1,2}$, Christelle Pomares ${ }^{1,2}$, Toxoplasma p35 Study Group ${ }^{\mathrm{a}}$

${ }^{1}$ Service de Parasitologie-Mycologie, CHU de Nice, Université Côte d'Azur, 06202 Nice, France

${ }^{2}$ Inserm U1065, C3M, 06204 Nice, France

${ }^{3}$ Service de Parasitologie-Mycologie, CHU de Toulouse, 31300 Toulouse, France

${ }^{4}$ PharmaDev, IRD UMR 152, Université de Toulouse, 31062 Toulouse, France

5 Service de Microbiologie, Hôpital La Source, CHR d'Orléans, 45100 Orléans, France

${ }^{6}$ Parasitologie-Mycologie, CHU de Nantes, 44093 Nantes, France

${ }^{7}$ Université de Nantes, Nantes Atlantique Universités, EA1155-IICiMed, Institut de Recherche en Santé 2, 44200 Nantes, France

${ }^{8}$ Institut de Parasitologie et de Pathologie Tropicale, EA 7292, Fédération de Médecine Translationnelle, Université de Strasbourg, 67000 Strasbourg, France

9 EA7510, ESCAPE, Laboratoire de Parasitologie-Mycologie, Université de Reims Champagne-Ardenne, SFR Cap Santé FED 4231, 51096 Reims, France

Received 3 December 2019, Accepted 29 January 2020, Published online 7 February 2020

\begin{abstract}
Background: Primary infection by Toxoplasma gondii in pregnant women can result in serious outcomes for the foetus. A false-positive IgG result during pregnancy can lead to a misdiagnosis of past infection and to stopping preventive measures. We collected 189 sera with positive Architect ${ }^{\circledR}$ Toxo IgG assay (Abbott Laboratories) and negative IgG results with at least two other serological tests, in order to find an explanation for the suspected false-positive IgG results. We used the recomLine Toxoplasma $\operatorname{IgG}^{\circledR}$ immunoblot (Mikrogen Diagnostik) to search for specific antigenic reactivities of the sera, and the LDBio Toxo II $\mathrm{IgG}^{\circledR}$ immunoblot (LDBio Diagnostics) as a confirmatory test. Results: The bands GRA8 and/or GRA7 were positive for 148 samples (78.3\%). GRA8 was the most frequent band, appearing in 133 patterns (70.4\%), whereas GRA7 was present for 49 samples (25.9\%). Of the 81 samples tested with LDBio $^{\circledR}, 23(28.4 \%)$ turned out to be positive. Of the 58 negative LDBio ${ }^{\circledR}$ tests $(71.6 \%)$ (real false-positive Architect ${ }^{\circledR}$ IgG), 23 samples $(39.6 \%)$ did not show either a GRA8 or p30 band by recomLine ${ }^{\circledR}$. Their false positivity with Architect ${ }^{\circledR}$ remains unexplained since Abbott uses these two recombinant antigens for their assay. Conclusions: The Architect ${ }^{\circledR} \operatorname{IgG}$ false positivity for $T$. gondii seems to be due to reactivity against GRA8 for the majority of the sera and GRA7 to a lesser extent. The hypothesis of past contact with parasites genetically close to T. gondii such as Hammondia hammondi or Neospora caninum seems promising and should be assessed further.
\end{abstract}

Key words: Toxoplasma gondii, IgG, False-positive, Serology, Architect, Toxoplasmosis.

Résumé - Diagnostic sérologique de Toxoplasma gondii : analyse des IgG faux positifs et implications. Contexte : La primo-infection à Toxoplasma gondii chez la femme enceinte peut avoir de graves conséquences pour le fœtus. Un résultat IgG faussement positif pendant la grossesse peut mener à un diagnostic erroné d'infection ancienne et à stopper les mesures préventives. Nous avons collecté 189 sérums présentant un résultat Architect ${ }^{\circledR}$ Toxo IgG (Abbott Laboratories) positif ainsi qu'un résultat IgG négatif par au moins deux autres tests sérologiques, dans le but de trouver une explication aux résultats IgG suspectés faux positifs. Nous avons utilisé l'immunoblot recomLine Toxoplasma $\operatorname{IgG}^{\circledR}$ (Mikrogen Diagnostik) pour chercher certaines réactivités antigéniques spécifiques des sérums et l'immunoblot LDBio Toxo II IgG ${ }^{\circledR}$ (LDBio Diagnostics) comme test de confirmation. Résultats : Les bandes GRA8 et/ou GRA7 étaient positives pour 148 (78,3\%) échantillons. GRA8 était la bande la plus fréquente, apparaissant dans $133(70,4 \%)$ profils alors que GRA7 était présente pour 49 (25,9\%) échantillons. Sur les 81 échantillons testés en LDBio $^{\circledR}, 23(28,4 \%)$ se sont révélés positifs. Sur les $58(71,6 \%)$ tests LDBio $^{\circledR}$ négatifs (réels faux positifs IgG Architect $\left.{ }^{\circledR}\right), 23(39,6 \%)$ échantillons n'ont montré ni bande GRA8 ni bande p30 en recomLine ${ }^{\circledR}$ et leur fausse

*Corresponding author: simon. 1@chu-nice.fr

${ }^{\mathrm{a} T o x o p l a s m a}$ p35 Study Group: Jean-François Carod, Bernard Cimon, Rita Donsimoni, Valérie Ernault, Hélène Fricker-Hidalgo, Juliette Gillon, Nadine Godineau, Géraldine Gonfrier, Marie Hautecoeur, Stéphane Liguori, Marie-Noëlle Noulard, Hervé Pelloux, Cécile Poggi. 


\begin{abstract}
positivité reste donc inexpliquée puisque Abbott utilise ces deux antigènes recombinants dans son test. Conclusions : La fausse positivité IgG Architect ${ }^{\circledR}$ pour $T$. gondii semble être due à une réactivité envers la protéine GRA8 pour la majorité des sérums et envers GRA7 dans une moindre mesure. L'hypothèse d'un contact passé avec des parasites génétiquement proches de $T$. gondii comme Hammondia hammondi ou Neospora caninum semble prometteuse et devrait être approfondie.
\end{abstract}

\section{Introduction}

Toxoplasmosis is a parasitic disease due to Toxoplasma gondii, an obligate intracellular protozoan with a worldwide distribution. The life cycle of the parasite involves sexual reproduction in definitive hosts from the Felidae family, and a broad range of intermediate hosts including mammals and birds [18, 26, 30, 41, 46, 47]. Human infection occurs mainly by ingestion of $T$. gondii oocysts present on raw and unwashed vegetables, and through consumption of raw or undercooked meat containing cysts of the parasite [6, 22, 48]. Although T. gondii primary infection is usually asymptomatic in the healthy population, it can be life-threatening for others, like immunocompromised patients. In these hosts, acute infection or reactivation of a past infection can lead to severe and possibly lethal diseases (cerebral, pulmonary, or disseminated toxoplasmosis) [25, 27, 40]. In particular, primary infection in pregnant women and reactivation in immunocompromised pregnant women can be the cause of congenital toxoplasmosis with the risk of serious outcomes for the foetus, mainly retinitis pigmentosa, hydrocephaly, or even death in utero [4, 24, 44].

In some countries, the health authorities have set up a prenatal screening program for $T$. gondii [33, 34, 43]. In France, pregnant women are tested in the early weeks of pregnancy for the presence of specific $\operatorname{IgG}$ and $\operatorname{IgM}$ against $T$. gondii. The presence of $T$. gondii $\operatorname{IgG}$ at a stable level without $\operatorname{IgM}$ is in favour of a past infection. These women are considered to be immunised against $T$. gondii and follow-up is no longer performed. In seronegative pregnant women, monthly screening will be performed to allow early diagnosis and treatment of an acute infection in order to prevent transplacental transmission of the parasite to the foetus [43]. This highlights the importance of an accurate and reliable test for the detection of specific $\mathrm{IgG}$, given that a false-positive result can lead to a misdiagnosis of past infection, and to stopping surveillance and preventive measures in a pregnant woman.

Currently, many serological tests are available for IgG detection with different sensitivities and specificities. Studies on the Architect ${ }^{\circledR}$ Toxo IgG assay (Abbott Laboratories, North Chicago, IL, USA) show specificities and sensitivities ranging from $99.1 \%$ to $99.8 \%$ and $92.1 \%$ to $99.7 \%$, respectively $[17,29,32,37,42]$. This assay is based on the principle of chemiluminescent microparticle immunoassay (CMIA). According to the manufacturer, Architect ${ }^{\circledR}$ uses two T. gondii recombinant antigens for the immunoassay: a membrane protein of $30 \mathrm{kDa}(=\mathrm{p} 30)$ called SAG1 (surface antigen 1), only found in the tachyzoite stage of the parasite; and a cytoplasmic protein of $35 \mathrm{kDa}(=\mathrm{p} 35)$ called GRA8 (dense granule), found in the tachyzoite and bradyzoite stages of the parasite. Similarly, studies on other commonly used automated or semiautomated immunoassays (Advia Centaur ${ }^{\circledR}, \mathrm{AxSym}^{\circledR}$, Elecsys $^{\circledR}$, Enzygnost $^{\circledR}$, Liaison $^{\circledR}$, Platelia $^{\circledR}$, Vidas $^{\circledR}$, and Vidia ${ }^{\circledR}$ ) show various specificities from $99.3 \%$ to $100 \%$, while sensitivities range from $93.8 \%$ to $100 \%$ [32, 42]. Since the specificity is not $100 \%$ for some of these assays, pregnant women are exposed to the risk of being misdiagnosed as immunised, whereas they are not. In our article, we will focus on Architect ${ }^{\circledR}$ in order to find a rational explanation for the suspected falsepositive Architect ${ }^{\circledR}$ Toxo IgG results. To our knowledge, this is the first study that tries to provide an explanation for discordant $T$. gondii $\mathrm{IgG}$ test results.

\section{Materials and methods \\ Sample collection}

The laboratory of Parasitology-Mycology at the University Hospital of Nice, France (Nice laboratory) is a member of the National Reference Centre for toxoplasmosis (Reims, France). This laboratory regularly receives human serum samples from other laboratories throughout France, in order to provide expertise for serological diagnosis of toxoplasmosis. From July 2009 to April 2018, sera from other laboratories with discordant T. gondii IgG results between different serological assays were sent to the Nice laboratory. The samples included in this study came from 21 cities in mainland France (Angers, Antibes, Arras, Embrun, Fréjus, Grenoble, Lisieux, Miramas, Nantes, Nice, Orléans, Reims, Saint-Denis, Saint-Etienne-du-Rouvray, Saint-Laurent-du-Var, Salon-de-Provence, Strasbourg, Toulon, and Toulouse), from the island of Corsica (Ajaccio), and French Guiana in South America (Saint-Laurent-du-Maroni); in addition to the samples from the Nice laboratory (Table 1).

\section{Study design}

Sera with positive Architect ${ }^{\circledR}$ Toxo IgG test result and negative test result found by at least one other IgG assay were selected for further analyses. According to the manufacturer's instructions, the Architect ${ }^{\circledR}$ Toxo $\operatorname{IgG}$ assay is considered positive when the titre is $\geq 3 \mathrm{IU} / \mathrm{mL}$. The other serological test results came from the following assays: Platelia ${ }^{\circledR}$ Toxo IgG (Bio-Rad, Hercules, CA, USA), AxSym ${ }^{\circledR}$ Toxo IgG (Abbott Laboratories), Toxolatex Fumouze ${ }^{\circledR}$ (Biosynex, Eckbolsheim, France), Pastorex ${ }^{\mathrm{TM}}$ Toxo (Bio-Rad), Modified Agglutination Test (MAT), Toxo-Spot IF $^{\circledR}$ (bioMérieux, Marcy-l'Étoile, France), and Vidas ${ }^{\circledR}$ Toxo IgG II (bioMérieux). In case only one of these assays was performed, the Nice laboratory performed a Vidas ${ }^{\circledR}$ Toxo IgG II analysis. When a Vidas ${ }^{\circledR}$ test result was the only one available, a Toxo-Screen DA ${ }^{\circledR}$ (bioMérieux) was performed. For sera from the Nice laboratory, the $\operatorname{Vidas}^{\circledR}$ and Toxo-Screen $\mathrm{DA}^{\circledR}$ assays were always performed as part of the routine procedure of the laboratory. We grouped all these eight assays under the name 
Table 1. Origin of the samples.

\begin{tabular}{lc}
\hline City & Number of sera \\
\hline Private laboratories & 2 \\
Embrun & 2 \\
Lisieux & 1 \\
Miramas & 2 \\
Saint-Etienne-du-Rouvray & 1 \\
Saint-Laurent-du-Var & 1 \\
Salon-de-Provence & \\
Hospital laboratories & 3 \\
Ajaccio (Corsica) & 4 \\
Angers & 1 \\
Antibes & 4 \\
Arras & 4 \\
Fréjus & 3 \\
Grenoble & 30 \\
Nantes & 60 \\
Nice & 10 \\
Orléans & 4 \\
Reims & 3 \\
Saint-Denis & 3 \\
Saint-Laurent-du-Maroni (French Guiana) & 5 \\
Strasbourg & 1 \\
Toulon & 45 \\
Toulouse & 189 \\
\hline Total &
\end{tabular}

"alternative tests". Thus, each serum was positive by Architect ${ }^{\circledR}$ Toxo IgG and negative by at least two assays among the alternative tests. Additionally, Architect ${ }^{\circledR}$ Toxo IgM (Abbott Laboratories) was performed for all the sera in the study, and test results were all negative (index $<0.6$ according to the manufacturer's instructions), except for one individual (Architect ${ }^{\circledR}$ IgM index = 1.8) whose positive $\operatorname{IgM}$ were later confirmed on another sample as non-specific $\operatorname{IgM}$.

To increase the power of the study, grey-zone $\operatorname{IgG}$ results by Architect $^{\circledR}$ were considered negative and were not included. Concerning the other three quantitative tests performed (Vidas $^{\circledR}$, Platelia ${ }^{\circledR}$, and AxSym ${ }^{\circledR}$ ), all IgG results obtained were below the grey-zone.

\section{Study population}

In total, 189 samples collected from 176 individuals presenting positive $\operatorname{IgG} \operatorname{Architect}^{\circledR}(\geq 3 \mathrm{IU} / \mathrm{mL})$ and negative $\mathrm{IgG}$ with at least two other serological tests were included in the study over a period of 9 years. The study population included 155 females $(88.1 \%)$ and 21 males $(11.9 \%)$. The mean age was 31.5 years, ranging from 1 to 87 years (including six children under 17 years).

\section{RecomLine ${ }^{\circledR}$ immunoblot}

The recomLine Toxoplasma $\mathrm{IgG}^{\circledR}$ immunoblot (Mikrogen Diagnostik, Neuried, Germany) was performed on the 189 sera. This immunoblot is able to discriminate antibodies against the recombinant proteins of $T$. gondii ROP1c (= p66), GRA1 $(=$ p24), GRA7 (= p29), GRA8 (= p35), SAG1 (= p30),
MAG1 (= p65, p68), and MIC3. An additional antigen called rSAG1 (= p30, low concentration) is loaded to the strip as a marker of past infection. We hijacked the initial purpose of this diagnostic test and used it solely to elaborate a pattern of antibody reactivity, by noting the positive bands among the eight recombinant antigens coated, for each serum tested.

\section{LDBio $^{\circledR}$ immunoblot}

Whenever possible, the LDBio Toxo II $\operatorname{IgG}^{\circledR}$ immunoblot (LDBio Diagnostics, Lyon, France) was performed on the samples. We used this assay as a confirmatory test of the absence or presence of specific anti-T. gondii $\operatorname{IgG}$ [14]. According to the manufacturer, a positive LDBio $^{\circledR}$ immunoblot is defined by three apparent bands including p30 among the five $T$. gondii natural antigens coated, of molecular weights $30 \mathrm{kDa}$ (= p30), $31 \mathrm{kDa}, 33 \mathrm{kDa}, 40 \mathrm{kDa}$, and $45 \mathrm{kDa}$. This assay was used to conclude whether the positive Architect ${ }^{\circledR}$ Toxo $\mathrm{IgG}$ test results were true- or false-positives.

\section{Protein BLAST analysis (Basic Local Alignment Search Tool)}

Protein sequences were blasted with NCBI's online alignment tool using substitution matrix BLOSUM62. Similarity scores are expressed in bits, and Expect values $(E$-values $) \leq 10 \mathrm{e}-10$ demonstrate significant homologies.

\section{Results}

\section{Serological tests results}

Across the 189 Architect $^{\circledR}$ Toxo IgG performed, the IgG values ranged from 3.0 to $235.1 \mathrm{IU} / \mathrm{mL}$; the median was $5.6 \mathrm{IU} / \mathrm{mL}$ with an interquartile range of $6.5 \mathrm{IU} / \mathrm{mL}$. Among the alternative tests, $157(83.1 \%)$ Toxo-screen ${ }^{\circledR}$ and $134(70.9 \%)$ Vidas $^{\circledR}$ were performed. All the other alternative tests performed are detailed in Table 2.

\section{RecomLine ${ }^{\circledR}$ immunoblot results}

We carried out 189 recom Line ${ }^{\circledR}$ tests in total and analysed the pattern of positive bands among the eight recombinant antigens for each serum (Fig. 1). In our full sample set, we found 20 different profiles in which zero to maximum three bands per immunoblot were found. The majority of the samples were only positive for the GRA8 band $(46.6 \%)$ but other frequent patterns were found, especially GRA8 + GRA7 (14.3\%) and GRA7 only $(6.9 \%)$. The remaining patterns included: SAG1 only $(1.6 \%)$, GRA 8 + SAG1 (1.6\%), GRA8 + ROP1c (1.6\%), ROP1c only $(1.1 \%)$, GRA 8 + SAG1 + ROP1c $(1.1 \%)$, GRA 8 + GRA7 + GRA1 (1.1\%), GRA8 + GRA7 + ROP1c $(1.1 \%)$, GRA 8 + GRA7 + SAG1 (1.1\%), MIC3 only $(0.5 \%)$, GRA1 only $(0.5 \%)$, GRA 8 + GRA1 $(0.5 \%)$, GRA 8 + MAG1 $(0.5 \%)$, GRA $8+$ MIC3 (0.5\%), GRA7 + GRA1 (0.5\%), GRA8 + GRA7 + MAG1 (0.5\%), and GRA7 + GRA1 + ROP1c $(0.4 \%)$. In $18 \%$ of the samples, the immunoblots did not show any positive band. 
Table 2. Diagnostic tests performed.

\begin{tabular}{lccc}
\hline Analysis & $\begin{array}{c}\text { Number } \\
\text { of sera }\end{array}$ & Negative (\%) & Positive (\%) \\
\hline Architect $^{\circledR}$ Toxo IgG & 189 & $0(0)$ & $189(100)$ \\
Toxo-Screen DA $^{\circledR}$ & 157 & $157(100)$ & $0(0)$ \\
Vidas $^{\circledR}$ Toxo IgG & 134 & $134(100)$ & $0(0)$ \\
Platelia $^{\circledR}$ Toxo IgG & 63 & $63(100)$ & $0(0)$ \\
AxSYM $^{\circledR}$ Toxo IgG & 21 & $21(100)$ & $0(0)$ \\
Toxolatex Fumouze $^{\circledR}$ & 10 & $10(100)$ & $0(0)$ \\
Toxo-Spot IF $^{\circledR}$ & 8 & $8(100)$ & $0(0)$ \\
Pastorex $^{\text {TM Toxo }}$ & 7 & $7(100)$ & $0(0)$ \\
Modified Agglutination Test $^{\circledR}$ & 4 & $4(100)$ & $0(0)$ \\
LDBio-Toxo II IgG $^{\circledR}$ & 81 & $58(71.6)$ & $23(28.4)$ \\
\hline
\end{tabular}

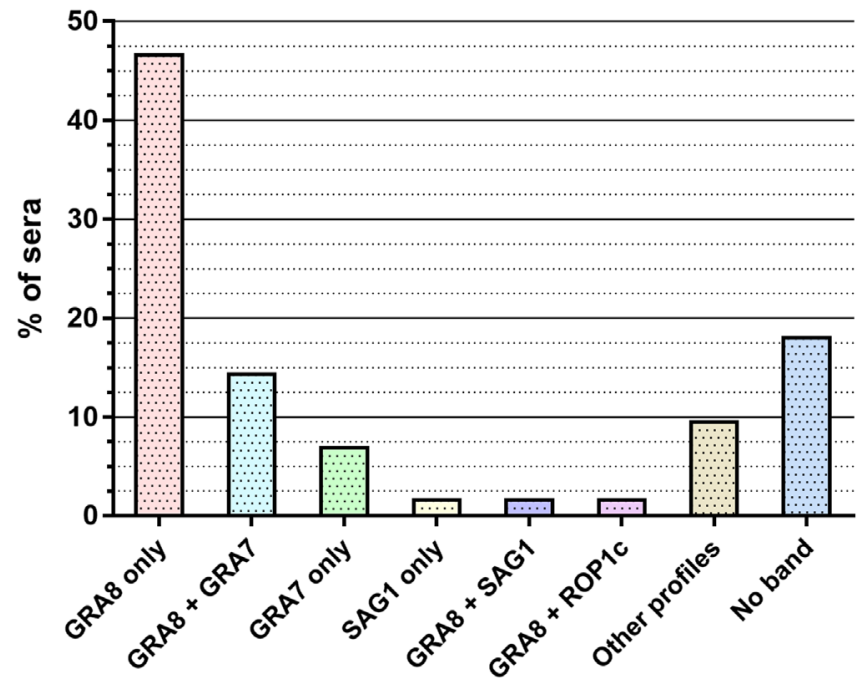

Figure 1. Description of the recomLine ${ }^{\circledR}$ immunoblot profiles performed on the 189 suspected false-positive sera with Architect ${ }^{\circledR}$.

Taking into account all the patterns, we found GRA8 and/or GRA7 bands for 148 samples $(78.3 \%)$. GRA8 was the most frequent band, appearing in total in 133 patterns $(70.4 \%)$, whereas GRA7 was present for 49 samples (25.9\%). We did not observe any specific pattern according to age or gender categories.

\section{LDBio ${ }^{\circledR}$ immunoblot results}

We were able to perform $81 \mathrm{LDBio}^{\circledR}$ tests on the leftover serum. Of these 81 samples tested, $23(28.4 \%)$ turned out to be positive despite their 2-4 negative alternative tests (Table 2 and Supplementary Table 1). Most of the positive samples had similar profiles with LD Bio ${ }^{\circledR}: 21$ of them presented apparent bands at $30 \mathrm{kDa}, 31 \mathrm{kDa}$, and $40 \mathrm{kDa}$. The remaining two samples presented apparent bands at $30 \mathrm{kDa}, 31 \mathrm{kDa}$, $33 \mathrm{kDa}$, and $40 \mathrm{kDa}$. The Architect ${ }^{\circledR}$ Toxo IgG values for these sera ranged from 3.2 to $30.4 \mathrm{IU} / \mathrm{mL}$, the median was $6.6 \mathrm{IU} / \mathrm{mL}$ with an interquartile range of $10.1 \mathrm{IU} / \mathrm{mL}$. Moreover, 58 samples $(71.6 \%)$ presented a negative $\mathrm{LDBio}^{\circledR}$ test and were considered true false-positive Architect ${ }^{\circledR}$ IgG results. As for the results of the recomLine ${ }^{\circledR}$ immunoblots, there was no specific result according to age or gender.

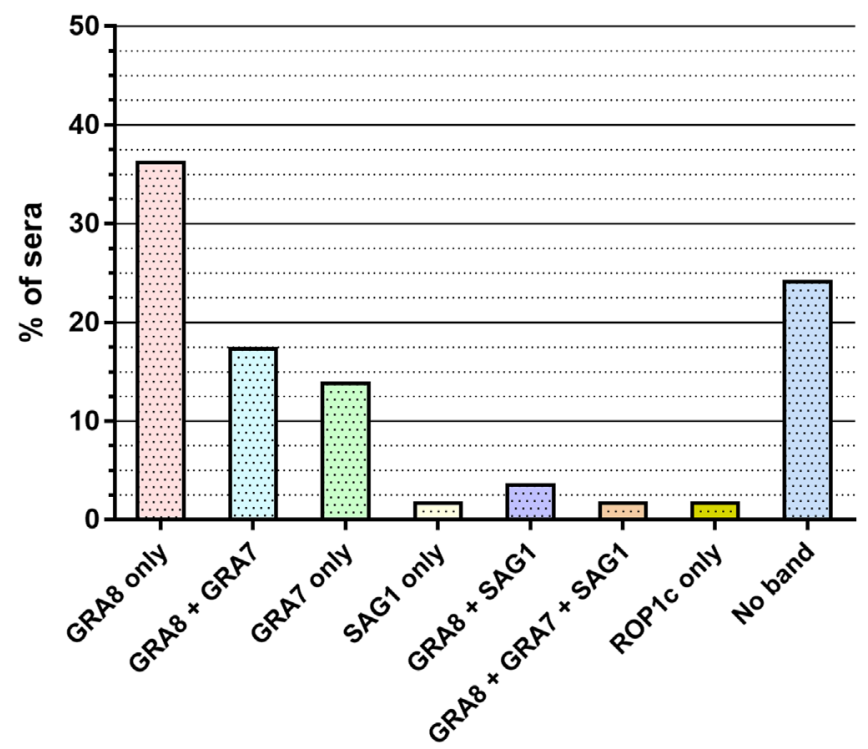

Figure 2. Description of the recomLine ${ }^{\circledR}$ immunoblot profiles (for the 58 negative $\mathrm{LDBio}^{\circledR}$ tests considered true false-positive sera with Architect $^{\circledR}$ ).

\section{Analysis of the combined immunoblots results}

The negative $\mathrm{LDBio}^{\circledR}$ profiles are further detailed in Figures 2 and 3. Concerning these samples, recomLine ${ }^{\circledR}$ immunoblots show that GRA8 (p35) and/or SAG1 (p30) appeared in 35 samples $(60.4 \%)$ (including 31 profiles $(53.5 \%)$ with GRA8, $1(1.7 \%)$ with SAG1 and 3 (5.2\%) with GRA8 + SAG1) (Figs. 2 and $3 \mathrm{~A})$. This may explain the false positivity with Architect ${ }^{\circledR}$, which uses the recombinant antigens GRA8 and p30. On the other hand, 23 samples (39.6\%) did not show either a GRA8 or p30 band and yet were positive with $\operatorname{Architect}^{\circledR}$ (Figs. 2 and $3 \mathrm{~A})$. In detail, for these samples, recomLine ${ }^{\circledR}$ patterns showed no band for 14 samples (24.1\%), only GRA7 for 8 samples (13.8\%), and only ROP1c for 1 sample $(1.7 \%)$. For the samples containing the GRA 8 band by recomLine ${ }^{\circledR}$, the majority $(50 \%)$ presented a p30 + p40 LDBio $^{\circledR}$ profile and 5 samples $(15 \%)$ did not present any band by LDBio $^{\circledR}$ (Fig. 3B). Of the 4 samples containing the SAG1 band by recomLine ${ }^{\circledR}, 1$ presented a p30 band by LDBio $^{\circledR}$ (Fig. 3C). Concerning the samples without any recomLine ${ }^{\circledR}$ band, $36 \%$ also did not present any band by $\mathrm{LDBio}^{\circledR}$, and $57 \%$ presented a p30 band (Fig. 3D).

For the 23 positive $\mathrm{LDBio}^{\circledR}$ tests, all the samples presented the GRA8 band by recomLine ${ }^{\circledR}$. Although all the positive LDBio $^{\circledR}$ tests had a p30 band by definition, 1 out of 23 presented the SAG1 band by recomLine ${ }^{\circledR}$.

Among the $81 \mathrm{LDBio}^{\circledR}$ tests performed, 33 showed only the GRA8 band by recomLine ${ }^{\circledR}$, of which 12 samples $(36.4 \%)$ were positive and $21(63.6 \%)$ were negative by $\mathrm{LDBio}^{\circledR}$.

\section{Protein BLAST analysis}

To assess the possibility of other cross-reactivities, we blasted protein sequences of $T$. gondii GRA8, GRA7, and SAG1 (p30) (Table 3). First, the T. gondii GRA8 protein 


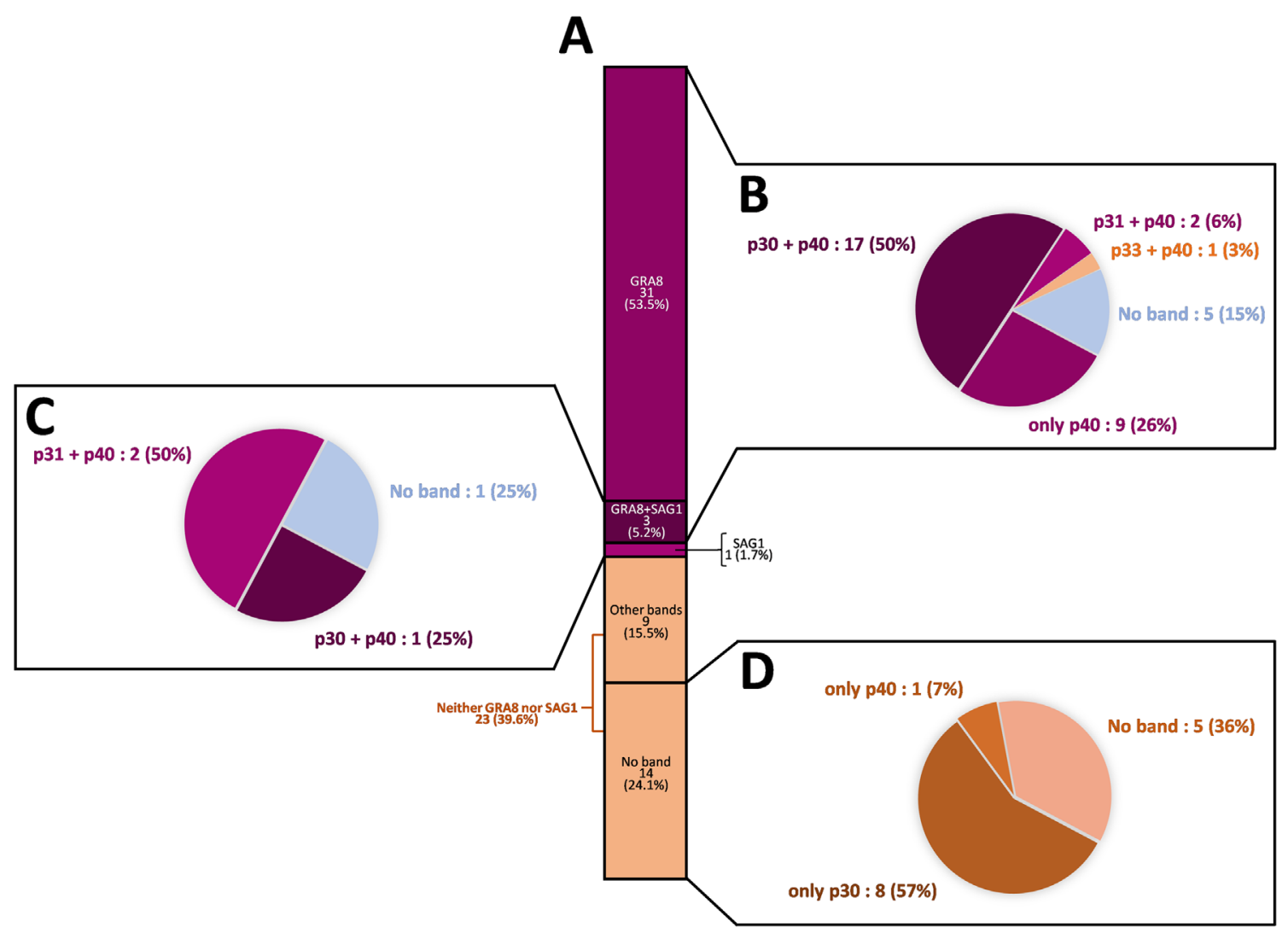

Figure 3. Description of the immunoblot profiles of the 58 negative LDBio ${ }^{\circledR}$ tests (true false-positives with Architect ${ }^{\circledR}$ ). (A) Proportion of recomLine ${ }^{\circledR}$ profiles positive for GRA8, SAG1, GRA8+SAG1, other bands or no band, among the 58 negative LDBio ${ }^{\circledR}$ tests. (B) LDBio ${ }^{\circledR}$ profiles of the GRA8-positive recomLine ${ }^{\circledR}$ profiles. (C) LDBio ${ }^{\circledR}$ profiles of the SAG1-positive recomLine ${ }^{\circledR}$ profiles. (D) LDBio ${ }^{\circledR}$ profiles of the "no band" recomLine ${ }^{\circledR}$ profiles.

Table 3. Protein BLAST analysis.

\begin{tabular}{|c|c|c|c|c|c|c|}
\hline Blasted proteins & Bitscore & $E$-value & Query cover $(\%)$ & Identities $(\%)$ & Positives $(\%)$ & Gaps $(\%)$ \\
\hline T. gondii GRA8 vs. H. hammondi GRA8 & 275.0 & $2 \mathrm{e}-89$ & 100 & 75 & 82 & 1 \\
\hline T. gondii GRA7 vs. H. hammondi GRA7 & 260.0 & $4 \mathrm{e}-84$ & 99 & 60 & 70 & 2 \\
\hline T. gondii GRA8 vs. T. gondii GRA7 & 12.7 & 9.1 & 4 & 50 & 58 & 41 \\
\hline T. gondii GRA7 vs. $N$. caninum 021640 & 68.6 & $3 e-10$ & 91 & 36 & 47 & 21 \\
\hline T. gondii $\mathrm{p} 30$ vs. N. caninum $\mathrm{P} 36$ & 317.0 & $5 e-104$ & 94 & 52 & 66 & 1 \\
\hline
\end{tabular}

showed high similarity to the Hammondia hammondi GRA8 protein (dense granule) in the Protein BLAST analysis. In the same way, the $T$. gondii GRA7 protein showed strong similarity with the $H$. hammondi GRA7 protein. Moreover, it also seems to have sequence homology with the uncharacterised protein NCLIV_021640 from the parasite Neospora caninum. On the other hand, there is no significant homology between $T$. gondii GRA7 and GRA8 proteins. Concerning T. gondii p30, its sequence homology with $N$. caninum surface protein P36 is substantial.

\section{Discussion}

All serological methods can provide false-positive results, irrespective of the infectious disease tested. The Architect ${ }^{\circledR}$
Toxo IgG assay is currently one of the most commonly used for T. gondii serological diagnosis in France. In this study, we collected all suspected false-positive Architect ${ }^{\circledR} \operatorname{IgG}$ test results, regardless of the gender. Despite proven high specificity, the few false-positive test results are still a serious issue, particularly for pregnant women. In immunocompromised patients, reactivation of a past infection can be fatal, mainly from brain damage. In this specific population, a false-positive $\mathrm{IgG}$ test result can be misleading and appear to indicate cerebral toxoplasmosis, thus neglecting other differential diagnoses (e.g., cryptococcal meningitis or primary central nervous system lymphoma). In pregnant women, acute infection or reactivation of $T$. gondii can lead to a fatal outcome for the foetus. Importantly, a false-positive $\operatorname{IgG}$ test result in a pregnant woman can lead to stopping preventive measures, leading to the risk of an acute infection during pregnancy. In addition, 
false-positive IgG test results will make it difficult to diagnose an acute infection as it will be more difficult to differentiate the false-positive IgG from the neosynthesized ones of the acute infection. In such a situation, testing $\operatorname{IgM}, \operatorname{IgA}$, and avidity will be of utmost importance for the diagnosis. On the basis of our results, it seems that Architect $^{\circledR}$ IgG false positivity may be due to reactivity against GRA8 for the majority of the sera and GRA7 to a lesser extent. We also noted that a significant part of our samples did not present reactivity against any of the seven different recombinant proteins loaded on the recomLine ${ }^{\circledR}$ immunoblot.

Previous studies on $T$. gondii cross-reactivity and the BLAST analyses performed in this work have led us to take an interest in the protozoan $H$. hammondi. Hammondia hammondi is another obligate intracellular parasite that infects cats. It is closely relative to $T$. gondii in terms of morphology, biology and genetics [19, 35]; however, this parasite is not known to be infective in humans [45]. Its range of intermediate hosts seems to be more restrictive and includes mainly rodents [16]. Hammondia hammondi also produces a GRA8 protein (dense granule) so the hypothesis of cross-reactivity with some of its antigens should be assessed.

Given the BLAST analysis results, it would be interesting to test our samples for $N$. caninum too. This parasite, like $H$. hammondi, is not known to be infective in humans and is found in dogs and other mammals. As remarkably reviewed by Gondim et al., several studies in the past forty years have shown serological cross-reactivities and cross-immunity between T. gondii, H. hammondi, and N. caninum [19]. In vivo, rodents infected with $H$. hammondi developed immunity and were protected against $T$. gondii lethal dose infection [15]. It is interesting to note that the immunogenic potential seems to depend on the strains used for experiments [3]. Immunisation with $H$. hammondi protects goats from abortion induced by T. gondii [31]. Serological cross-reactivities have also been found between these two parasites in mice, rabbits, dogs, and pigs using immunofluorescence, haemagglutination, dye-test or ELISA [19]. In another study reviewed by Gondim et al., five T. gondii antigens of molecular weight $30,32,35,66$, and $90 \mathrm{kDa}$ were recognised using polyclonal anti-H. hammondi serum [35].

Concerning $N$. caninum, Gondim et al. reviewed studies showing that cross-immunity and protection of mice against $T$. gondii, after immunisation by $N$. caninum, are dependent on strains and doses used for experimental infections [19]. Serological cross-reactivities with $T$. gondii have also been a problem for the production of monoclonal antibodies against $N$. caninum [28, 39]. These findings highlight the fact that the strains of pathogens such as $H$. hammondi, $T$. gondii, and $N$. caninum are important in terms of cross-reactivity issues.

Moreover, the number of recomLine ${ }^{\circledR}$ immunoblots without any positive bands raises additional questions. Despite the fact that none of them had a positive LDBio $^{\circledR}$ test (defined by three bands including p30), some nonetheless showed a p30 band not found by recomLine ${ }^{\circledR}$. This inconsistency from one assay to another could be due to a difference of sensitivity between these two immunoblots. The LDBio ${ }^{\circledR}$ strips are indeed coated with natural $T$. gondii antigens, whereas recomLine ${ }^{\circledR}$ uses recombinant proteins.
Our results show that several negative serological tests do not guarantee true IgG negativity of the sera, given the positivity of $28.4 \%$ of the tested samples with the LDBio Toxo II $\mathrm{IgG}^{\circledR}$ confirmatory test. The main assumption that could explain this result is that individual variations in the quantity of circulating IgG are high after $T$. gondii infection. Very low titres could point out the lack of sensitivity of the automated assays compared to the $\mathrm{LDBio}^{\circledR}$ test facing such antibody titres.

As a reminder, the Architect ${ }^{\circledR}$ automated assay is based on the immune reactivity of the sera against the proteins p30 and GRA8. The discrepancies we found between the positivity with Architect $^{\circledR}$ and yet the absence of GRA8 or p30 bands in immunoblots make us wonder whether the antigens chosen for automated assays are the most suitable ones. Most manufacturers do not in fact indicate what antigens are used in their test, and this can also be entire T. gondii antigenic extracts. A comparison between the different assays is then difficult to perform. We might wonder why the GRA8 antigen was initially added to the Architect ${ }^{\circledR}$ IgG assay. Was the aim to increase sensitivity in the detection of past $T$. gondii infection or to allow earlier diagnosis of recent infection? Some previous studies seems to show that the recombinant GRA8 antigen allows for better diagnosis of acute toxoplasmosis rather than chronic infection [11,21]. Moreover, we can question whether the antibodies directed only against GRA8, as we highlighted in our study in $46.6 \%$ of samples, are sufficient to consider the patient immunised against $T$. gondii? In this regard, among the recomLine ${ }^{\circledR}$ tests only positive for GRA 8 and tested by $\mathrm{LDBio}^{\circledR}$, we found $36.4 \%$ positive and $63.6 \%$ negative confirmatory tests. Thus, in our sample set, some antibodies directed only against GRA8 could be considered true positive. The research is ongoing to find new efficient antigens. Innovative tools like bioinformatic analyses or epitope mapping have been developed and recent studies used chimeric antigens and multiepitope peptides for the diagnosis of acute and chronic infections [8, 10, 36]. Promising results in terms of sensitivity and specificity are available with these antigens, but more tests are needed to implement them in routine diagnostic practice [7, 20].

Since the selection of antigens for immunoassays remains an issue, the question becomes whether serological methods could be supplemented by other tests for the diagnosis of Toxoplasma infection. Humoral response of the host to the infection increases levels of circulating anti-Toxoplasma immunoglobulins. The different isotypes $\operatorname{IgG}, \operatorname{IgM}, \operatorname{IgA}$, and $\mathrm{IgE}$ are currently used for diagnosis and estimation of the date of infection in serological tests [8, 38]. However, immune response to $T$. gondii is processed for a significant part by cell-mediated immunity $[9,12]$. The first mechanism involved is a T-cell-independent response. T. gondii activates microbicidal functions of macrophages and synthesis of gamma interferon (IFN- $\gamma$ ) by natural killer cells [9]. The second mechanism involves interleukin-12 release by the macrophages, in response to the infection, to allow synthesis of IFN- $\gamma$ by Toxoplasma-specific $\mathrm{CD}^{+}$and $\mathrm{CD}^{+}{ }^{+}$T-cells through a Th1 immune response $[9,12] . \mathrm{IFN}-\gamma$ is thus important to control parasite replication during the acute and chronic phases of the infection.

New tools based on cell-mediated immunity should be developed in order to be used in routine laboratories for the 
diagnosis of $T$. gondii infection. First, fluorescence-activated cell sorting (FACS) methods have been developed to detect patient-specific T-cell activation in blood after in vitro incubation with $T$. gondii antigens $[13,23]$. More recently, the in vitro IFN- $\gamma$ production of patient $\mathrm{T}$ lymphocytes after contact with Toxoplasma antigens has been assessed in a new test based on the principle of the IFN- $\gamma$ assay, well described for the diagnosis of tuberculosis [1,2,5]. These tests were first designed to improve the diagnosis of congenital toxoplasmosis in infants born to mothers who seroconverted during pregnancy. Serological diagnosis of such patients is difficult since maternal Toxoplasma-specific IgG can cross the placenta, whereas the Toxoplasma IFN- $\gamma$ assay allows for direct assessment of newborn cell-mediated immunity. In addition, this test also showed very good performances on adult patients [1].

Altogether, our work shows that the GRA 8 and GRA7 proteins seem to be an avenue worth exploring to explain serological cross-reactivities. It highlights the importance of always confirming IgG positivity with at least another assay. False-positive samples cannot yet be avoided, even though they remain rare, and particular attention must be given to pregnant women with no proven past $T$. gondii infection. Serological tests have perhaps reached their limits and innovative tools such as cell-mediated immunity-based assays could become a valuable aid for toxoplasmosis diagnosis in the near future.

\section{Conflict of interest}

The authors declare that Abbott Laboratories provided the recomLine ${ }^{\circledR}$ kits used to perform part of the analyses.

\section{Supplementary materials}

Supplementary material is available at https://www. parasite-journal.org/10.1051/parasite/2020006/olm

Supplementary Table 1. Detailed results of all tests performed.

Acknowledgements. We would like to thank the private laboratories of Embrun, Lisieux, Miramas, Saint-Etienne-du-Rouvray, SaintLaurent-du-Var, and Salon-de-Provence for sending us samples of interest for our study.

\section{References}

1. Chapey E, Wallon M, Debize G, Rabilloud M, Peyron F. 2010. Diagnosis of congenital toxoplasmosis by using a whole-blood gamma interferon release assay. Journal of Clinical Microbiology, 48, 41-45.

2. Chapey E, Wallon M, L'Ollivier C, Piarroux R, Peyron F. 2015. Place of interferon- $\gamma$ assay for diagnosis of congenital toxoplasmosis. Pediatric Infectious Disease Journal, 34, 1407-1409.

3. Christie E, Dubey JP. 1977. Cross-immunity between Hammondia and Toxoplasma infections in mice and hamsters. Infection and Immunity, 18, 412-415.

4. Chuang Y-C, Chen J-Y, Ji D-D, Su P-H. 2012. Congenital toxoplasmosis in a neonate with significant neurologic manifestations. Journal of the Formosan Medical Association, 111, 232-233.
5. Ciardelli L, Meroni V, Avanzini MA, Bollani L, Tinelli C, Garofoli F, Gasparoni A, Stronati M. 2008. Early and accurate diagnosis of congenital toxoplasmosis. Pediatric Infectious Disease Journal, 27, 125-129.

6. Cook AJC, Gilbert RE, Buffolano W, Zufferey J, Petersen E, Jenum PA, Foulon W, Semprini AE, Dunn DT. 2000. Sources of Toxoplasma infection in pregnant women: European multicentre case-control study. British Medical Journal, 321, 142-147.

7. Dai J, Jiang M, Wang Y, Qu L, Gong R, Si J. 2012. Evaluation of a recombinant multiepitope peptide for serodiagnosis of Toxoplasma gondii Infection. Clinical and Vaccine Immunology: CVI, 19, 338-342.

8. Dard C, Fricker-Hidalgo H, Brenier-Pinchart M-P, Pelloux H. 2016. Relevance of and new developments in serology for Toxoplasmosis. Trends in Parasitology, 32, 492-506.

9. Denkers EY, Gazzinelli RT. 1998. Regulation and function of T-cell-mediated immunity during Toxoplasma gondii infection. Clinical Microbiology Reviews, 11, 569-588.

10. Döşkaya M, Liang L, Jain A, Can H, Gülçe İz S, Felgner PL, Değirmenci Döşkaya A, Davies DH, Gürüz AY. 2018. Discovery of new Toxoplasma gondii antigenic proteins using a high throughput protein microarray approach screening sera of murine model infected orally with oocysts and tissue cysts. Parasites \& Vectors, 11, 393.

11. Drapała D, Holec-Gaôsior L, Kur J. 2015. New recombinant chimeric antigens, P35-MAG1, MIC1-ROP1, and MAG1ROP1, for the serodiagnosis of human toxoplasmosis. Diagnostic Microbiology and Infectious Disease, 82, 34-39.

12. Dupont CD, Christian DA, Selleck EM, Pepper M, LeneyGreene M, Harms Pritchard G, Koshy AA, Wagage S, Reuter MA, Sibley LD, Betts MR, Hunter CA. 2014. Parasite fate and involvement of infected cells in the induction of CD4+ and CD8+ T cell responses to Toxoplasma gondii. PLoS Pathogens, 10, e1004047.

13. Fatoohi AF, Cozon GJN, Gonzalo P, Mayencon M, Greenland T, Picot S, Peyron F. 2004. Heterogeneity in cellular and humoral immune responses against Toxoplasma gondii antigen in humans. Clinical and Experimental Immunology, 136, 535-541.

14. Franck J, Garin YJ-F, Dumon H. 2008. LDBio-Toxo II immunoglobulin G Western Blot confirmatory test for antitoxoplasma antibody detection. Journal of Clinical Microbiology, 46, 2334-2338.

15. Frenkel JK, Dubey JP. 1975. Hammondia hammondi gen. nov., sp. nov., from domestic cats, a new coccidian related to Toxoplasma and Sarcocystis. Zeitschrift für Parasitenkunde, 46, 3-12.

16. Frenkel JK, Dubey JP. 2000. The taxonomic importance of obligate heteroxeny: distinction of Hammondia hammondi from Toxoplasma gondii - another opinion. Parasitology Research, 86, 783-786.

17. Gay-Andrieu F, Fricker-Hidalgo H, Sickinger E, Espern A, Brenier-Pinchart M-P, Braun H-B, Pelloux H. 2009. Comparative evaluation of the ARCHITECT Toxo IgG, IgM, and IgG Avidity assays for anti-Toxoplasma antibodies detection in pregnant women sera. Diagnostic Microbiology and Infectious Disease, 65, 279-287.

18. Gazzonis AL, Zanzani SA, Santoro A, Veronesi F, Olivieri E, Villa L, Lubian E, Lovati S, Bottura F, Epis S, Manfredi MT. 2018. Toxoplasma gondii infection in raptors from Italy: seroepidemiology and risk factors analysis. Comparative Immunology, Microbiology and Infectious Diseases, $60,42-45$.

19. Gondim LFP, Mineo JR, Schares G. 2017. Importance of serological cross-reactivity among Toxoplasma gondii, Hammondia spp., Neospora spp., Sarcocystis spp. and Besnoitia besnoiti. Parasitology, 144, 851-868. 
20. Hajissa K, Zakaria R, Suppian R, Mohamed Z. 2017. An evaluation of a recombinant multiepitope based antigen for detection of Toxoplasma gondii specific antibodies. BMC Infectious Diseases, 17, 807.

21. Hiszczyńska-Sawicka E, Kur J, Pietkiewicz H, Holec-Gasior L, Gasior A, Myjak P. 2005. Efficient production of the Toxoplasma gondii GRA6, p35 and SAG2 recombinant antigens and their applications in the serodiagnosis of toxoplasmosis. Acta Parasitologica, 50, 249-254.

22. Jones JL, Dubey JP. 2012. Foodborne toxoplasmosis. Clinical Infectious Diseases, 55, 845-851.

23. Kahi S, Cozon GJ, Peyron F. 1999. Early detection of cellular immunity in congenitally Toxoplasma gondii-infected children. Pediatric Infectious Disease Journal, 18, 846-847.

24. Khan K, Khan W. 2018. Congenital toxoplasmosis: an overview of the neurological and ocular manifestations. Parasitology International, 67, 715-721.

25. Khurana S, Batra N. 2016. Toxoplasmosis in organ transplant recipients: evaluation, implication, and prevention. Tropical Parasitology, 6, 123-128.

26. Laforet CK, Deksne G, Petersen HH, Jokelainen P, Johansen MV, Lassen B. 2019. Toxoplasma gondii seroprevalence in extensively farmed wild boars (Sus scrofa) in Denmark. Acta Veterinaria Scandinavica, 61, 4.

27. Lee S-B, Lee T-G. 2017. Toxoplasmic encephalitis in patient with acquired immunodeficiency syndrome. Brain Tumor Research and Treatment, 5, 34-36.

28. Liao M, Xuan X, Huang X, Shirafuji H, Fukumoto S, Hirata H, Suzuki H, Fujisaki K. 2005. Identification and characterization of cross-reactive antigens from Neospora caninum and Toxoplasma gondii. Parasitology, 130, 481-488.

29. Mahinc C, Flori P, Delaunay E, Guillerme C, Charaoui S, Raberin H, Hafid J, L'Ollivier C. 2017. Evaluation of a new immunochromatography technology test (LDBio diagnostics) to detect Toxoplasma IgG and IgM: comparison with the routine architect technique. Journal of Clinical Microbiology, 55, 3395-3404.

30. Meng Q-F, Li D, Yao G-Z, Zou Y, Cong W, Shan X-F. 2018. Seroprevalence of Toxoplasma gondii infection and variables associated with seropositivity in donkeys in eastern China. Parasite, 25, 66.

31. Munday BL, Dubey JP. 1988. Prevention of Toxoplasma gondii abortion in goats by vaccination with oocysts of Hammondia hammondi. Australian Veterinary Journal, 65, 150-153.

32. Murat J-B, Dard C, Fricker Hidalgo H, Dardé M-L, BrenierPinchart M-P, Pelloux H. 2013. Comparison of the Vidas system and two recent fully automated assays for diagnosis and follow-up of toxoplasmosis in pregnant women and newborns. Clinical and Vaccine Immunology, 20, 1203-1212.

33. Pomares C, Montoya JG. 2016. Laboratory diagnosis of congenital toxoplasmosis. Journal of Clinical Microbiology, 54, 2448-2454.

34. Prusa A-R, Kasper DC, Sawers L, Walter E, Hayde M, Stillwaggon E. 2017. Congenital toxoplasmosis in Austria: prenatal screening for prevention is cost-saving. PLoS Neglected Tropical Diseases, 11, e0005648.

35. Riahi H, Bouteille B, Darde ML. 1998. Antigenic similarity between Hammondia hammondi and Toxoplasma gondii tachyzoites. Journal of Parasitology, 84, 651-653.
36. Rostami A, Karanis P, Fallahi S. 2018. Advances in serological, imaging techniques and molecular diagnosis of Toxoplasma gondii infection. Infection, 46, 303-315.

37. Sickinger E, Gay-Andrieu F, Jonas G, Schultess J, Stieler M, Smith D, Hausmann M, Stricker R, Stricker R, Dhein J, Braun H-B. 2008. Performance characteristics of the new ARCHITECT Toxo IgG and Toxo IgG Avidity assays. Diagnostic Microbiology and Infectious Disease, 62, 235-244.

38. Smets A, Fauchier T, Michel G, Marty P, Pomares C. 2016. Comparison of Toxoplasma gondii $\mathrm{IgG}$ avidity Architect and Vidas assays with the estimated date of infection in pregnant women. Parasite, 23, 45.

39. Sohn CS, Cheng TT, Drummond ML, Peng ED, Vermont SJ, Xia D, Cheng SJ, Wastling JM, Bradley PJ. 2011. Identification of novel proteins in Neospora caninum using an organelle purification and monoclonal antibody approach. PloS One, 6, e18383.

40. Sonneville R, Magalhaes E, Meyfroidt G. 2017. Central nervous system infections in immunocompromised patients. Current Opinion in Critical Care, 23, 128-133.

41. Villagra-Blanco R, Barrantes-Granados O, Montero-Caballero D, Romero-Zúñiga JJ, Dolz G. 2019. Seroprevalence of Toxoplasma gondii and Neospora caninum infections and associated factors in sheep from Costa Rica. Parasite Epidemiology and Control, 4, e00085.

42. Villard O, Cimon B, L'Ollivier C, Fricker-Hidalgo H, Godineau N, Houze S, Paris L, Pelloux H, Villena I, Candolfi E. 2016. Help in the choice of automated or semiautomated immunoassays for serological diagnosis of toxoplasmosis: evaluation of nine immunoassays by the french national reference center for toxoplasmosis. Journal of Clinical Microbiology, 54, 3034-3042.

43. Wallon M, Peyron F, Cornu C, Vinault S, Abrahamowicz M, Kopp CB, Binquet C. 2013. Congenital Toxoplasma infection: monthly prenatal screening decreases transmission rate and improves clinical outcome at age 3 years. Clinical Infectious Diseases, 56, 1223-1231.

44. Wallon M, Garweg JG, Abrahamowicz M, Cornu C, Vinault S, Quantin C, Bonithon-Kopp C, Picot S, Peyron F, Binquet C. 2014. Ophthalmic outcomes of congenital toxoplasmosis followed until adolescence. Pediatrics, 133, e601-608.

45. Walzer KA, Adomako-Ankomah Y, Dam RA, Herrmann DC, Schares G, Dubey JP, Boyle JP. 2013. Hammondia hammondi, an avirulent relative of Toxoplasma gondii, has functional orthologs of known T. gondii virulence genes. Proceedings of the National Academy of Sciences of the United States of America, 110, 7446-7451.

46. Wang X, Qin S-Y, Liu Z-L, Zhang X-T, Cui D-Y, Li J-H, Liu Y, Zhao Q, Ni H-B. 2019. Seroprevalence and risk factors of Toxoplasma gondii infection in domestic raccoon dogs in four provinces in northern China. Microbial Pathogenesis, 128, 136-138.

47. Zhang X-X, Qin S-Y, Li X, Ren W-X, Hou G, Zhao Q, Ni H-B. 2018. Seroprevalence and related factors of Toxoplasma gondii in pigeons intended for human consumption in Northern China. Vector Borne and Zoonotic Diseases, 19, 302-305.

48. Zhou Q, Wang Q, Shen H, Zhang Y, Zhang S, Li X, Acharya G. 2018. Seroepidemiological map of Toxoplasma gondii infection and associated risk factors in preconception period in China: a nationwide cross-sectional study. Journal of Obstetrics and Gynaecology Research, 44, 1134-1139. 
Reviews, articles and short notes may be submitted. Fields include, but are not limited to: general, medical and veterinary parasitology; morphology, including ultrastructure; parasite systematics, including entomology, acarology, helminthology and protistology, and molecular analyses; molecular biology and biochemistry; immunology of parasitic diseases; host-parasite relationships; ecology and life history of parasites; epidemiology; therapeutics; new diagnostic tools.

All papers in Parasite are published in English. Manuscripts should have a broad interest and must not have been published or submitted elsewhere. No limit is imposed on the length of manuscripts.

Parasite (open-access) continues Parasite (print and online editions, 1994-2012) and Annales de Parasitologie Humaine et Comparée (1923-1993) and is the official journal of the Société Française de Parasitologie. 